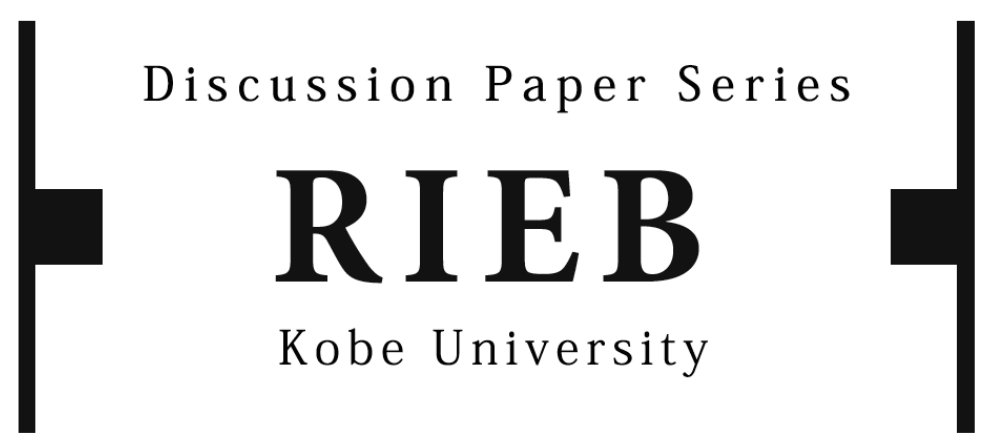

DP2013-10

Financial Crisis in Asia:

Its Genesis, Severity and Impact on Poverty and Hunger *

\author{
Katsushi S. IMAI \\ Raghav GAIHA \\ Ganesh THAPA
}

Samuel Kobina ANNIM

March 27, 2013

* The Discussion Papers are a series of research papers in their draft form, circulated to encourage discussion and comment. Citation and use of such a paper should take account of its provisional character. In some cases, a written consent of the author may be required.

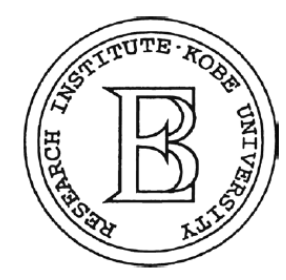

Research Institute for Economics and Business Administration Kobe University 


\title{
Financial Crisis in Asia: Its Genesis, Severity and Impact on Poverty and Hunger
}

\author{
Katsushi S. Imai \\ University of Manchester, United Kingdom \& Kobe University, Japan \\ Raghav Gaiha \\ Massachusetts Institute of Technology, United States of America \& University of Delhi, \\ India \\ Ganesh Thapa \\ International Fund for Agricultural Development, Italy \\ \& \\ Samuel Kobina Annim \\ University of Manchester, United Kingdom
}

$27^{\text {th }}$ March 2013

\begin{abstract}
Building on the recent literature on finance, growth and hunger, we have examined the experience of Asian countries over the period 1960-2010 by dynamic and static panel data models. We have found evidence favouring a positive role of finance - defined as private credit by banks - on growth of GDP and agricultural value added. Private credit as well as loans from the World Bank significantly reduces undernourishment, while remittances and loans from microfinance institutions appear to have a negative impact on poverty. Our empirical evidence shows that growth performance was significantly lower during the recent global financial crisis than non-crisis periods, though the severity is much smaller during the recent financial crisis than Asian financial crisis.
\end{abstract}

Key Words: Finance, Economic Development, Agriculture, Inequality, Poverty, Asia JEL Code: C33, E44, G01, I32, O15

The project was initially funded by IFAD (International Fund for Agricultural Development). We are grateful to Thomas Elhaut, former) Director of Asia and the Pacific Division, IFAD, for his support and guidance. The first author thanks generous research support from RIEB, Kobe University, during his stay in 2010. The second acknowledges generous support of Bish Sanyal, Department of urban Studies, MIT. Raghbendra Jha's help with the econometric analysis is greatly appreciated, as also valuable research assistance by Valentina Camaleonte and Sundeep Vaid. We are indebted to guest editors, David Lawson and Ed Amann, and participants in the Second Annual ESRC Development Economics Conference "The Effects of the Financial Crisis on Developing Countries" at Manchester in January 2010 for their useful comments. The present version has benefitted from valuable comments from an anonymous referee. The views expressed are, however, those of the authors' and do not necessarily represent those of the organisations to which they are affiliated.

Corresponding Author: Katsushi Imai (Dr), Economics, School of Social Sciences, Arthur Lewis Building, University of Manchester, Oxford Road, Manchester M13 9PL, UK Phone: +44-(0)161275-4827; Fax: +44-(0)161-275-4928; E-mail: Katsushi.Imai@manchester.ac.uk. 


\section{Financial Crisis in Asia: Its Genesis, Severity and Impact on Poverty and Hunger}

\section{Introduction}

There are a number of studies that focused on the financial crisis that erupted in USA in 2008 and rapidly spread to the rest of the world (e.g., IMF, 2008, World Bank, 2008a, ADB, 2008, Arrow, 2008, Krugman, 2008, Phelps, 2008). Indeed, this crisis has turned into a crisis of confidence. Despite extensive interventions by governments and monetary authorities, the supply of credit shrank, stock markets recorded dramatic losses, and a major downturn occurred in the global economy. Commodity prices eased from the earlier peaks-especially during 2007-08 which sparked riots in many developing countries- and large exchange rate realignments occurred shortly after the crisis (ADB, 2008, 2010, FAO, 2009, IMF, 2008, 2010. In fact, as emphasised by Rodrik (2010), developing countries have been prone to a series of crises - some financial and others of a different kind - with devastating consequences for the poor. He observes "For too many of these countries, economic growth in the last two decades relied on a combination of two factors: a natural rebound from previous financial crises (as in Latin America) or political conflicts and civil war (as in Africa), and high commodity prices. Neither can be relied on for the productive transformation that developing countries need" (Rodrik, 2010, no page number).

An observation on the classification of the 2008-09 crisis as financial is pertinent. As the financial crisis evolved into an economic crisis through its linkages with the real economy for example, through trade channels - several recent commentators prefer to characterise the recent crisis as economic. As an important analytical concern of our study is comparison of this crisis with an earlier Asian financial crisis of 1997-98, we stick with the classification of the former as financial without overlooking the trade channels.

However, regarding the impact of the financial crisis which started in 2008, there is consensus about the extent to which it affected economic growth and poverty in the 
developing world. Two studies in this volume offer insightful accounts. Indonesia fared reasonably well in the financial crisis of 2008/2009 (Mc Culloch and Grover, 2013). The macroeconomic shock it suffered was much less than those of neighbouring countries and slowed slightly its growth rate. There was little evidence of sub-groups which were particularly badly affected, although the impact of the crisis on migrant workers is understated by the data. A surprising result is that the period between August 2008 and February 2009 saw large increases in real wages for employees over 25. Although real wages in mining, agriculture and public utilities fell, reflecting the collapse in commodity prices, wages in industry, construction and transport, and communications increased quickly. There are several reasons why Indonesia was affected mildly. One is structural - Indonesia, as a large country, is much less dependent on international trade than most other countries in the region. The large drop in exports and imports therefore had a commensurately smaller effect on the domestic economy. Moreover, the government's macroeconomic management of this crisis was good. Confidence was restored to the market, limiting the fall in the value of the currency, and hastening its early recovery. Briefly, the Indonesian experience has useful broader lessons about the impact of the crisis. First, the nature of the shock was confined to export sectors, particularly commodities and manufacturing. Second, monetary management prevented a long-lasting shock to the exchange rate, while a long period of prudential budget management had created the fiscal space for Indonesia to respond.

During the global recession in 2008-2009, Sub-Saharan Africa (SSA)'s GDP growth fell substantially. But, fortunately, the decline was much lower than in the rest of the world. Besides, SSA showed greater resilience during the present crisis than in previous ones (Fosu, 2013). Some conjectures are offered. First, the global environment has changed significantly, with emerging developing countries like China and India currently assuming a much larger portion of Africa's trade than previously. As these economies were less adversely affected by 
the crisis, SSA would be similarly so, via the trade shock channel. Second, economic and political governance have improved for SSA as a whole, enabling measures to mitigate the economic impact of the crisis. Such instruments include fiscal thrust or accommodating monetary policy, and in the political context, constraints on the executive, among others. In conclusion, although SSA was hurt by the recent economic crisis, it has weathered the storm much better than previously without seriously disrupting the pre-crisis steady march toward economic and human development.

Set against these and other important recent contributions, the main objective of the present study is to deepen our understanding of the severity of the financial crisis and its implications for growth and poverty reduction in selected Asian countries. While our focus is mainly on the recent global financial crisis, our econometric analysis is designed to yield insights into the channels through which the effects of financial crisis on growth and poverty were transmitted in developing countries. Comparison will be made between the recent global financial crisis and the Asian Financial Crisis in 1997-98 in terms of their severity. In fact, there is a body of empirical literature to assess the effects of financial crises on growth and/or poverty, using micro data sets. Most of these studies have confirmed negative impacts of crises on growth and poverty reduction (e.g., the Latin American Crisis (Oscar, 1998), the Asian Financial Crisis (Nixson and Walters, 1999; Mazumdar and Horton, 2000) the Russian Crisis (Lokshin and Ravallion, 2000)). ${ }^{1}$ But, to our knowledge, there have been no studies to assess the effects of the recent crisis on growth and poverty using a detailed data set. To better understand the implications of the recent financial crisis for economic growth and poverty, the present study carries out cross-country regression analysis for a sample of Asian countries in 1960-2010.

\footnotetext{
${ }^{1}$ However, using panel data, Stillman and Thomas (2008) found a weak impact of the Russian crisis on nutritional status.
} 
The scheme is as follows. The next section sets the stage for our analysis, by linking finance and the real economy, and through a brief exposition of the dynamics of the financial crisis and how the crisis unfolded in Asia. The impact of the financial crisis on microfinance given the latter's increasingly important role in reducing poverty in Asian countries - is also reviewed. Section III is devoted to a review of the literature on finance, growth and poverty. The data, model specifications and results are discussed in Sections IV and V, primarily to illustrate how credit influences growth and poverty reduction. In Section VI, concluding observations are made from a broad policy perspective.

\section{Backgrounds}

\section{Linkages between Finance and Real Economy}

While the linkages between finance and real economy remain contentious, various studies have focused on the following routes (IMF, 2008). The first is through a financial accelerator that amplifies the effects of financial cycles on the real economy specifically, its effects on the value of collateral and thereby expansion of credit. Another is through lenders' balance sheets and the relationship between bank capital and aggregate credit. When bank capital is eroded, banks become reluctant to lend and are forced to deleverage. A third but overlapping with the first linkage is the variation in the role of the financial accelerator with the financial system (arm's length financing as opposed to relationship banking). In other words, households and producers can substitute away from banks to markets (ibid, 2008). No less important are the trade linkages focused on contraction of exports to developed countries that were badly hit by the financial crisis.

The dynamics of the financial crisis could be delineated as follows: the procyclical behaviour of bank leverage - changes during upturns and downturns is crucial to understanding how banking stress translates into a reduced credit supply, a higher cost of 
capital, and a flattening of economic activity. More specifically, the key issue is: when banks overextend their balance sheets during booms, on the back of higher asset values and lower perceived risks, financial imbalances build up, economic activity is further boosted that, in turn, further boosts asset values, reduces perceived risk, fostering further lending and economic expansion. Under such conditions, a financial shock that either increases risks or reduces yields prompts a cycle of deleveraging, with a sharp reduction in bank lending as bank capital falls, leading to an economic slowdown that feeds into a further reduction in credit supply. The procyclicality of bank leverage is greater when banks are more exposed to fluctuations in the market value of assets-for example, through their holdings of securities and their repurchase. IMF (2008) confirms that commercial banks tend to be more procyclical when operating in arm's length financial systems in which a greater share of intermediation occurs through financial markets rather than through traditional relationship-based (and bank dominated) activities. Thus, arm's length financial systems are more prone to financial crises.

The channels through which the financial crisis impacted on growth and poverty in developing countries are diverse (Lin and Martin, 2010). These include changes in capital flows, commodity prices, remittances, interest rates, risk premia, and trade opportunities. The channels through which rural poor were impacted are even more complex, with linkages involving commodity prices, wage rates and employment likely to be particularly important.

To elaborate selectively, the effects of changes in commodity prices are complex. Declines in the prices of staple foods typically reduce poverty in developing countries, as the poor spend a large share of their incomes on these foods, and many poor in rural areas including small farmers are net buyers of these foods (Ivanic and Martin, 2008). Declines in the prices of some higher income-elastic foods such as dairy products, however, increase poverty by lowering the incomes of small producers who produce and sell these commodities but are unable to afford them. Declines in the prices of cash crops (e.g. cotton, coffee, rubber) 
are, however, more likely to increase poverty as farmers in developing countries are net sellers of these goods and the poor spend only small shares of their incomes on them.

A related observation is that income reductions increase not just poverty but also nutritional deprivation. Through a lower demand for calories, proteins and fats, and consequently lower intake, productivity is lowered and employment in rural labour markets is hampered. Thus nutrition-poverty traps emerge (Dasgupta and Ray, 1986, and Jha et al. 2009). Evidence also suggests that large sections of rural poor are also more vulnerable to shocks and crises than the non-poor, and shocks propel them into long spells of poverty (Gaiha and Imai, 2009, Dercon and Christiansen, 2011). Finally, as the poor are more creditconstrained, contraction of microcredit and more stringent selection criteria are likely to hurt the poor more. ${ }^{2}$

\section{How did the Crisis Unfold in Asia?}

The crisis manifested itself in emerging Asia in late 2008, and was initially expected to worsen in response to slackening demand from advanced economies and growing tensions in regional financial markets. Later assessments, however, pointed to a strong recovery led by China, India and other emerging Asian economies (ADB, 2010, IMF, 2010).

Table 1 and Appendices 1 and 2 largely confirm the view that Asia was not affected as much by the global financial crisis in 2008 as by the Asian Financial Crisis in 1997-98. Table 1 reviews the changes of GDP per capita growth, poverty head count ratio, private credit as a share of GDP, and export share in GDP before and after the Asian financial crisis as well as the global financial crisis for East Asia and Pacific (EAP), South Asia (SA) and

\footnotetext{
${ }^{2}$ For assessment of poverty alleviation role of microfinance from micro and macro perspectives, see Imai, Arun and Annim (2010) and Imai et al. (2012).
} 
Sub-Saharan Africa (SSA). ${ }^{3}$ These figures for selected countries are shown in Appendices 1 and 2.

(Table 1 to be inserted around here)

The first panel of Table 1 shows that economic growth slowed down in 2008 in EAP, SA and SSA, most notably in SA. While SSA's growth rate reduced to $-0.5 \%$ in 2009 , both EAP and SA made a sharp recovery in 2009-10 (World Bank, 2012). This V-shaped recovery is similar in the case of Asian financial crisis for EAP and SA, while the damage during the crisis (broadly inferred from the figures of GDP per capita in 1998 and 2008) was much severer for EAP in 1998 (than in 2008) and for SA in 2008 (than in 1998). On the other hand, poverty headcount at US $\$ 2$ a day steadily declined after the crisis with the exception of SSA where it only marginally declined from $77.5 \%$ in 1996 to $77.4 \%$ in 1999.

Following Fosu (2013), Mc Culloch and Grover (2013) and others, the present study takes into account both "trade effects" and "finance effects" associated with the crisis. Table 1 focuses on both private credit as well as export - defined as shares of GDP. It is striking to find that private credit was not much affected, or even increased during both crises with the exceptions of EAP in which private credit reduced by $2.8 \%$ in 2008 from the pre-crisis level (with a sharp recovery in 2009 to the level much higher than those in pre-crisis years), and SSA where it reduced by $8 \%$ in 2008 and recovered to the pre-crisis level in $2010 .{ }^{4}$ Exports were not much affected either with the exceptions of SSA in 1998 and EAP in 2008. It is noted that EAP reduced its export share in GDP further down to $34.5 \%$ in 2009 (from $46.2 \%$ in 2006).

\footnotetext{
${ }^{3}$ Only the countries classified by the World Bank as developing are included. The selection of the regions is guided by the fact that these regions still have a large number of the poor. The figures for other regions will be furnished on request.

${ }^{4}$ Other aggregate credit indicators (e.g. financial deposit or credit given by broader financial institutions) show similar trends.
} 
Appendices 1 and 2 break down the figures in Table 1 for selected Asian countries. As the space is limited, only a few observations on the 2008-09 crisis are made below. Financial markets weakened due to a pessimistic global outlook and investor risk appetite declined following the turbulence in September in 2008 and plummeting of equity markets. Current accounts began to show strains as well in these countries, largely due to rising import bills for commodities and slowing export growth. In consequence, India's growth rate fell to $3.4 \%$ in 2008 (down from $8.2 \%$ in 2007) and China's fell to $9.0 \%$ in 2008 (from $13.6 \%$ in 2007), while export share declined after the crisis only in China $^{5}$ (Appendix 2). Growth and export figures vary among other Asian countries, while the negative impact was generally much smaller in 2008 than in 1998. It is notable that Bangladesh, Indonesia, Vietnam and Lao PDR kept relatively high growth figures before and after the 2008 crisis, while Pakistan, Malaysia, the Philippines, Thailand, Cambodia, Kazakhstan, and Kyrgyz Republic had one year of negative growth rate after the crisis with varying stability. Apart from China, Malaysia, Pakistan, the Philippines, Nepal and Kazakhstan saw declining exports after the 2008 crisis. However, most of the countries have seen broadly steady decline in poverty after the 2008 crisis. This is in sharp contrast to the Asian financial crisis which increased poverty in Indonesia and the Philippines. Only countries which experienced contraction of credit in 2008 were China, Sri Lanka, Malaysia and Myanmar.

\section{Impact of Financial Crisis on Microfinance}

Microfinance allows poor people to protect, diversify and increase their incomes. Microfinance also mitigates vulnerability to extreme fluctuations that are a feature of their daily existence. Loans, savings, and insurance smooth out income fluctuations and stabilize consumption levels even during lean periods (Littlefield et al. 2003). Using data of 655 microfinance institutions across 80 countries in 2000-2009, Wagner and Winkler (2012)

\footnotetext{
${ }^{5}$ Growth rate of merchandise exports in China plummeted from 28.9 per cent in 2007 to 13.7 per cent in 2008 (ADB, 2010).
} 
showed that the crisis considerably reduced credit growth of microfinance institutions - most notably in Eastern Europe and Central Asia - and suggested that microfinance is vulnerable to crisis. To the extent that there is contraction of credit, and concomitant reduction in rural credit, the implications for the rural poor are likely to be serious. Even though interest rates have fallen to stimulate demand for credit, there is a strong reluctance to lend in an environment lacking trust. So, effectively, contraction of credit implies higher interest rates and shorter maturities. If these observations have general validity, it follows that the demand for credit would be reduced especially in the target groups of microfinance institutions (MFIs), and poverty may increase through financial constraints on raising agricultural productivity. Vulnerability of low income households may also get aggravated because of their failure to smooth consumption. On the other hand, the loan portfolio of MFIs may shift in favour of wealthier clients. Moreover, financial viability may erode because of moral hazard and adverse selection. A major priority therefore is to inject more capital into the financial system-especially MFIs (Microcredit Summit Campaign, 2008). Associated with the vulnerability of MFIs is the larger risk of mission drift and abandonment of their social objectives. Given the evidence on microfinance reducing poverty across developing countries (Imai et al., 2012), we will also consider the impact of microfinance in our econometric analysis.

\section{Review of Cross-Country Studies on Finance, Growth and Poverty}

There is a vast literature on this theme with valuable insights from cross-country data over time. We will concentrate on Beck et al. (2007) and Claessens and Feijen (2006) with brief comments on a few other important contributions. Beck et al. (2007) examine the effects of financial development on poverty through two channels: aggregate growth, and changes in the distribution of income. Instead of examining the finance-growth link, they offer an 
assessment of the impact of financial development on changes in the distribution of income and changes in both relative and absolute poverty. Specifically, the variables considered are (i) the Gini coefficient of income distribution; (ii) income share of the poor, measured as the income share of the poorest quintile relative to total national income; and (iii) the share of the population living on less than US\$1 per day. Using GMM panel estimator for dynamic models, they show that greater financial development is associated with poverty reduction. In fact, 60 per cent of the impact of financial development on the poorest quintile works through aggregate growth and 40 per cent through reduction in income inequality ${ }^{6}$.

Claessens and Feijen (2006) identify specific channels through which financial development impacts on undernourishment ${ }^{7}$. Using data from 1980-2003 and relying on IV estimation for robustness, they show that private credit has a large negative effect on undernourishment through higher agricultural productivity in general and higher livestock, crop and cereal yields in particular. To a large extent higher agricultural productivity due to financial development is mediated by greater fertilizer and tractor use. Besides, the distribution of banking outlets makes a difference. The present study builds upon Beck et al. (2007) and Claessens and Feijen (2006), among others.

\section{Data and Models for Finance, Growth and Hunger in Asia}

Here the objective is to analyse the relationships between finance, growth and hunger/ poverty in selected Asian countries. The analysis is based on a panel of 9 countries (Bangladesh, China, India, Indonesia, Malaysia, Pakistan, Philippines, Thailand, and Vietnam $)^{8}$ over the period 1960 to 2010 , based on dynamic and static panel estimations.

\footnotetext{
${ }^{6}$ Honohan (2003) shows that a 10 per cent increase in private credit to GDP reduces poverty by $2.5-3$ percent.

${ }^{7}$ Undernourishment is defined as "the condition of people whose dietary energy consumption is continuously below a minimum dietary energy requirement for maintaining a healthy life and carrying out a light physical activity" (FAOSTAT, 2008).

${ }^{8}$ Selection of the countries is guided by data availability.
} 


\section{Data}

All the models are estimated with the finance, poverty and inequality data at the country level. The data sets created are based on World Bank Development Indicators (WDI) 2012 (World Bank, 2012), World Bank's Finance Data (based on Beck and Demirgüç-Kunt 2009; Beck et al., 2000), The UNU-WIDER World Income Inequality Database (WIID) (UNU-WIDER, 2008), and Barro-Lee's (2011) data on education. One of the data constraints in addressing our research questions is that while annual data on most of the key economic and financial variables are available for 9 countries (except Vietnam for which most of the variables start from 1985-1990) in 1960-2010, the data on inequality and poverty are available only for those years in which a national income or expenditure survey or a census were carried out. Hence we use annual panel data for 8 or 9 countries to examine the links between financial growth and economic or agricultural growth in the period 1960-2010, with a few missing observations. To investigate the relationship between finance and inequality or poverty, we use the panel data aggregated at 5-year intervals since 1960 along the lines of Barro and Lee (2000) or the empirical macroeconomics literature to test growth theories. For all countries except Vietnam, inequality data from UNU-WIDER's WIID and undernutrition data from WDI are available roughly once or sometimes twice in 5-year periods. If more than one estimate is available in one period, the average is used. These poverty and inequality data are matched with the 5-year averages of finance and economic variables. One of the advantages of applying two different time schedules is that we can use the predicted values of finance data based on annual panel data for 5- year panel, whereby inequality or undernourishment is estimated by the aggregated finance data based on predictions on annual basis. This approach would at least partially address the issue of endogeneity of finance in the inequality or undernourishment equation. For annual data, we have specified a dynamic panel data model, drawing upon Blundell and Bond (1998) - an extension of Arellano and Bond (1991) to 
estimate GDP per capita, agricultural value added per worker and various finance variables. For 5- year average data, we used static panel data models, namely, fixed effects or random effects models given a few missing observations in poverty and inequality data as well as reduced number of observations as a result of averaging annual data.

Appendix 3 lists the definitions and descriptive statistics of the variables as well as data sources. We have taken three different measures of finance - (i) logarithm of the share of private credit in GDP; (ii) log of the share of private credit through (formal) money deposit banks as a share of GDP (the narrow definition of private credit), and (iii) log of Financial System Deposits in GDP, but we have mainly presented the results of (i). Because these are aggregative measures in nature, we have also used three additional finance or finance-related variables: total gross loan portfolio (GLP) of microfinance institutions (MFIs) aggregated for each country, loans from the World Bank groups (IBRD loans and IDA credits), and remittances (net remittance inflows as a share of GDP). For inequality, we use the income Gini coefficient. Undernourishment is the share of population below minimum level of dietary energy consumption. Poverty is defined as poverty headcount ratio at $\$ 2$ a day ${ }^{9}$. Other variables used in the analysis are defined in Appendix 3.

\section{Model Specifications}

We estimate two dynamic panel models in which the dependent variables comprise GDP per capita and finance, and three static panel models for inequality, undernourishment and poverty. A variable on finance predicted by the dynamic model is used as one of the explanatory variables for static models.

\section{(a) Model for GDP per capita}

Following Guariglia and Poncet (2008), we specify the following relation:

\footnotetext{
${ }^{9}$ Use of poverty headcount ratio at $\$ 1.25$ or poverty gaps for both thresholds have resulted inlead to broadly similar results.
} 
$\Delta Y_{i t}=\sum_{j=1}^{P} \alpha_{j} \Delta Y_{i t-j}+\beta_{1} F_{i t}+\beta_{2} T_{i t}+$ Control $_{i t} \cdot \beta_{3}+\beta_{4} D_{\text {Asian Crisis }_{t}}+\beta_{5} D_{\text {Financial Crisis }_{t}}+\eta_{i}+\varepsilon_{i t}$

where $i$ and $t$ denote country and year, respectively, $\Delta Y_{i t}$ is GDP per capita growth and $\Delta Y_{i t-j}$ is its $j^{\text {th }}$ lag. ${ }^{10} F_{i t}$ is a proxy variable for various variables on finance (e.g. private credit, MFI's total gross loan portfolio, public debt, remittances). $T_{i t}$, the sum of export and import as a share of GDP, is supposed to capture the trade openness effect. Control $_{i t}$ is a vector of control variables, such as, education (log of the share of main working age population (25 years or above) with primary education or above), log of government education in GDP to measure size of government, and $\log$ of CPI (Consumer Price Index). $D_{\text {Asian }_{\text {Crisis }} t}$ and $D_{\text {Financial Crisis }}$, dummy variables for the Asian Financial Crisis (taking 1 for 1997 and 1998 0 otherwise ) and for the Global Financial Crisis (taking 1 for 2008 or 2009 and 0 otherwise) are included to see the effects of crises on the growth performance ${ }^{11} . \eta_{i}$ is the country specific unobservable effect (e.g. social and cultural factors) and $\varepsilon_{i t}$ is an error term, independent, and identically distributed (or i.i.d.). To see how the effect (or slope) of $F_{i t}$ or $T_{i t}$ on growth is significantly different during the Asian financial crisis or the global financial crisis (in comparison with non-crisis periods), we have included the interacted terms with $D_{\text {Asian Crisis }_{t}}$ (or $D_{\text {Financial Crisis }}$ ) as specified by equation (1)'. This specification is useful to address "trade effects" and "finance effects" of the crisis (Fosu, 2013) indirectly. That is, if the interaction terms were negative and statistically significant, the effect of trade or finance on economic growth was supposed to be dampened during the crisis periods.

$$
\begin{aligned}
& \Delta Y_{i t}=\sum_{j=1}^{P} \alpha_{j} \Delta Y_{i t-j}+\beta_{1} F_{i t}+\beta_{2} T_{i t}+\operatorname{Control}_{i t} \cdot \beta_{3}+\beta_{4} D_{\text {Asian Crisis }_{t}}+\beta_{5} D_{\text {Financial Crisis }_{t}}+\beta_{6} D_{\text {Asian Crisis }_{t}} * \\
& F_{i t}+\beta_{7} D_{\text {Asian Crisis }_{t}} * T_{i t}+\beta_{8} D_{\text {Financial Crisis }_{t}} * F_{\text {it }}+\beta_{9} D_{\text {Financial Crisis }_{t}} * T_{i t}+\eta_{i}+\varepsilon_{i t}
\end{aligned}
$$

\footnotetext{
${ }^{10}$ As an extension, we have applied the same specification for agricultural value added per worker given the importance of agricultural sector in these Asian countries.

${ }^{11}$ We can include the time effect term in the two-way error model (Baltagi, 2005), but to see the impact of crises clearly, we have introduced two dummy variables instead. Inclusion of time effects will not change the main results.
} 
A version of equation (1) or (1)' can be written by replacing all the explanatory variables (except lagged dependent variables) by a vector of $\boldsymbol{X}_{i t}$.

$Y_{i t}-Y_{i t-1}=\left(\alpha^{\prime}-1\right) Y_{i t-1}+\boldsymbol{X}_{i t} \beta^{\prime}+\eta_{i}+\varepsilon i t$

with log of lagged per capita GDP on the right hand side. Estimating (1) (with log of lagged per capita GDP) is thus equivalent to estimating the following standard dynamic panel data model:

$Y_{i t}-Y_{i t-1}=\left(\alpha^{\prime}-1\right) Y_{i t-1}+\boldsymbol{X}_{i t} \beta^{\prime}+\eta_{i}+\varepsilon_{i t}$

$Y_{i t}=\alpha^{\prime} Y_{i t-1}+\boldsymbol{X}_{i t} \beta^{\prime}+\eta_{i}+\varepsilon_{i t}$

GMM panel estimator relies on first-differencing the estimating equation (and thus country fixed effects will be eliminated) and appropriate lags of the right side variables as instruments.

$Y_{i t}-Y_{i t-1}=\alpha^{\prime \prime}\left(Y_{i t-1}-Y_{i t-2}\right)+\left(\boldsymbol{X}_{i t}-\boldsymbol{X}_{i t-1}\right) \beta^{\prime \prime}+\left(\varepsilon_{i t-} \varepsilon_{i t-1}\right)$

Two issues have to be resolved: one is endogeneity of the regressors and the second is the correlation between $\left(Y_{i t-1}-Y_{i t-2}\right)$ and $\left(\varepsilon_{\left.i t-\varepsilon_{i t-1}\right)}\right.$ (e.g. see Baltagi, 2005, Chapter 8). Assuming that $\varepsilon_{i t}$ is not serially correlated and that the regressors in $\boldsymbol{X}_{i t}$ are weakly exogenous, the generalized method-of-moments (GMM) first difference estimator (e.g. Arellano and Bond, 1991) can be used. Alternatively, we could use the lagged differences of all explanatory variables as instruments for the level equation and combine the difference equation (3) and the level equation (2) in a system whereby the panel estimators use instrument variables based on previous realisations of the explanatory variables as the internal instruments, using the Blundell-Bond (1998) system GMM estimator based on additional moment conditions. Such a system gives consistent results under the assumptions that there is no second order serial correlation and the instruments are uncorrelated with the

\footnotetext{
${ }^{12}$ As an extension, we have also implemented the case with the first and second lagged dependent variables in some cases, depending on the results of serial correlation tests and significance of coefficient estimates of the lagged dependent variables.
} 
error terms. Validity of instruments is tested by Sargan's J test and the second order serial correlation of the residuals. The Blundell-Bond system GMM estimator is used in the present study. This estimator is useful to address the problem of potentially endogenous regressors (e.g. finance in equation (1)). In the system equation, endogenous variables can be treated similarly to lagged dependent variables. The second lagged levels of endogenous variables could be specified as instruments for difference equation. The first lagged differences of those variables could also be used as instruments for the level equation in the system. We try the cases (i) where the endogeneity is not taken into account, and (ii) where some endogenous variables (after instrumenting) are included. In this model, we try the cases where finance and trade share are treated as endogenous variables.

\section{(b) Model for Financial Development}

While there is a huge empirical literature on the determinants of finance, we use a simple specification, following Baltagi et al.'s (2009) where finance is estimated by a dynamic panel model in which trade openness and financial openness are used as explanatory variables.

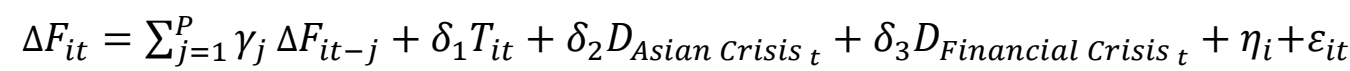

This equation is also estimated by the Blundell-Bond system GMM estimator.

\section{(c) Model for Inequality, Undernourishment and Poverty}

Due to the small number of observations for 5-years average data and missing observations, we have applied static panel models, namely, fixed-effects or random effects model.

$G_{i t^{\prime}}=\theta_{0}+\theta_{1}{\widehat{F_{l t}}}_{i t},+W_{i t^{\prime}} \cdot \theta_{2}+\theta_{3} D_{\text {Asian }_{\text {Crisis }}{ }^{\prime}}+\theta_{4} D_{\text {Financial Crisis }_{t^{\prime}}}+\eta_{i}+\varepsilon_{i t \prime}$

The dependent variable is the Gini index of income and denoted as $G_{i t^{\prime}}$. Here $t^{\prime}$ stands for 5year averages $(1960-64,1961-65, \ldots, 2005-9)$, which is distinguished from $t$, or annual data.

${\widehat{F_{l t}}}_{i t}$, is 5- year average of $\log$ of finance (i.e., private credit, total gross loan portfolio of 
MFIs, public debt, remittances) predicted by the equation (4). $W_{i t}$ is a vector of control variables, such as the share of working age population with primary education or above, population growth, and dependency ratio (the share of population below 15 years old or 65 years old), all in $\log .{ }^{13}$ In this case, $D_{\text {Asian Crisis }}{ }$ is defined as a dummy variable for 1995-99 and $D_{\text {Financial Crisis } t^{\prime}}$ is for $2005-9$ for simplicity. We have also used the same specification for undernourishment and poverty.

\section{Econometric Results}

The results of the models specified above are discussed here. Table 2 reports the selected results where a dependent variable is log GDP per capita growth and 'log finance' is defined as private credit as a share of GDP (Cases 1-3), private credit given by banking sectors as a share of GDP (which follows a narrower definition as detailed in Appendix 3) (Case 4), total Gross Loan Portfolio of MFIs (Case 5), public debt to the World Bank groups (Cases 6-8) and net flow of remittances (Case 9). Only a summary of the results is given below.

\section{(Table 2 to be inserted around here)}

When we adopt a broader definition of finance, or private credit/GDP, the sign of finance is positive but not statistically significant (Cases 1-3). In Cases 1 and 2, credit or trade share is not treated as endogenous variables and in the latter, trade share or credit is interacted with crisis dummies. In Case 3 credit and trade are treated as endogenous variables. The first lag of $\log$ GDP per capita is positive and significant, while the second is negative and significant, suggesting persistence of growth with some adjustment in 2 years. It is noted that GDP per capita was significantly lower during the Asian financial crisis as well as during the recent global financial crisis than the levels in non-crisis years. However, we can also find that

\footnotetext{
${ }^{13}$ Trade share has been dropped because of the high level of correlation with education.
} 
growth performances of Asian countries were more severely affected by Asian financial crisis than the recent global financial crisis as the dummy variable for the former has a higher absolute value of coefficient estimate in all the cases.

The interaction of the 1997-8 dummy and trade share is negative and significant, which implies that the positive effect (or elasticity) of trade (0.0173) became negative $(-0.022)$ during the Asian Financial Crisis (Case 2). When we adopt the narrow definition of private credit restricting it to the credit given by banks, it is positive and significant. This signifies the role of banking sectors in promoting growth (Case 4). The coefficient of gross loan portfolio of MFIs is positive but not statistically significant (Case 5). 'Loans from the World Bank group' is statistically insignificant regardless of the specifications (Cases 6-8). Trade share is positive and significant in general in these cases, but, as in Case 7, the negative coefficient estimate of the 1997-8 dummy interacted with trade share implies that the effect of trade openness became negative during the Asian financial crisis. This was presumably because the countries more open to the rest of the economy are likely to be more vulnerable to the crisis. However, this did not happen during the global financial crisis. The interaction term of the 2008-9 dummy and loans from the World Bank group is found to be positive and significant, while the interaction between the 1997-8 dummy and the World Bank loans is negative and significant in Case 7. That is, the effect of loans from the World Bank group is significantly higher during the recent global financial crisis, but lower during the Asian financial crisis relative to non-crisis years. This may suggest that the effectiveness of World Bank loans has improved significantly during the recent financial crisis in enabling borrowing countries to achieve higher economic growth. Contrary to Imai et al. (2011), the coefficient estimate of remittances is negative and significant (Case 9) ${ }^{14}$. Overall, Table 2 shows that (i) growth performance of Asian countries was affected by the global financial

\footnotetext{
${ }^{14}$ Difference was mainly due to difference in specifications as well as sample countries and years included.
} 
crisis, and (ii) finance did not affect growth except in a few cases. Trade openness or education is a more important determinant of the growth. However, the effect of trade does not appear to be influenced by the global financial crisis. Also, government expenditure is positive and significant only in Case 9.

We have applied exactly the same specifications to agricultural value added per worker ${ }^{15}$. The results are very similar to those in Table 2, but we observe a few differences. First, both first and second lagged dependent variables are positive and significant, suggesting the strong persistence in agricultural value added. Second, private credit by banks as well as remittances cease to be significant. That is, finance does not much affect the growth performance of agricultural sectors. Third, government expenditure is positive and significant in all the cases.

Table 3 contains the results of the finance equation using different definitions of finance. We have tried the specification, as in the equation (4), as well as the one without crisis dummies in which GDP per capita and trade share are treated as exogenous variables in a parsimonious specification. Key results of the latter are summarised at the bottom of Table 3 . First, it is striking to find that private credit as a share of GDP during the Asian financial crisis as well as global financial crisis was significantly higher than in non-crisis periods in Case 1. It is often argued that credit supply tends to immediately contract after the crisis, but this claim has to be carefully re-examined. This is supported by Appendices 1 and 2 . Appendices 1 and 2 show that 13 out of the 17 Asian countries experienced an increase in private credit in 1998 as well as in 2008 from the pre-crisis levels of private credit. However, heterogeneity of the crisis impact among different countries should not be ignored because China or Malaysia experienced a drop in private credit in 2008. It is also notable that crisis dummies are positive, but not statistically significant if we adopt a narrow definition of private credit (Case 2). Microfinance and remittances significantly increased even during the

\footnotetext{
${ }^{15}$ The results will be furnished on request.
} 
Asian financial crisis. We do not find a positive and significant link between GDP per capita and finance (except case 4), but once we drop the crisis dummies and treat GDP per capita and trade share as exogenous variables, the coefficient estimate of GDP per capita becomes significant and positive for private credit and MFI loans. It is negative and significant for the loans from World Bank groups as poor countries tend to obtain loans in difficult times. Consistent with Baltagi et al. (2009), trade openness shows a positive and significant estimate in the parsimonious specification. Trade share is also positive and significant for loans from World Bank groups, but negative and significant for microfinance loans regardless of the specifications. The reasons are not clear, but we conjecture that the latter is affected by Bangladesh with a high value of MFI loans and a low level of trade openness.

Table 4 reports the results for the Gini coefficient as well as undernourishment while Table 5 presents those for poverty headcount ratio at US $\$ 2$ based on fixed-effects or random effects model. The choice of the model is guided by the Hausman test. To avoid cluttering the text, we focus only on key results associated with the effects of (predicted) finance on the dependent variables. Our explanations below draw mainly upon the cases preferred by the results of Hausman tests (shown in bold).

\section{(Table 4 to be inserted around here)}

In Table 4 inequality measured by the Gini coefficient is not significantly affected by finance variables if we focus on the cases chosen by Hausman tests. However, if we take the results in Cases 3 and 6 based on random-effects models, we find that inequality tends to be significantly reduced by either MFI loans (Case 3) or loans from the World Bank group (Case

6) presumably because these mainly target the poor. It is not certain whether education reduces inequality as the results are sensitive to specification. GDP deflator is not statistically significant in the cases chosen by Hausman tests. Crisis dummy variables are statistically 
insignificant, suggesting that inequality levels during the crisis periods were not much different from those in the non-crisis periods.

On the other hand, undernourishment is negatively and significantly associated with predicted values of private credit (Case 10) and loans from the World Bank groups (Case 12). The coefficient of remittances is positive, but not significant. Population growth tends to increase undernourishment (Case 13). No significant effects are observed for the Asian financial crisis dummy. The global financial crisis dummies have been dropped due to missing variables of undernourishment in recent years.

(Tables 4 to be inserted around here)

Table 5 shows a set of results in which poverty headcount ratio at US\$2 is estimated by using the same specification used for Gini or undernourishment. Most of the finance variables are statistically insignificant, but 'remittances' is negative and significant at the $10 \%$ level, which is consistent with poverty reducing roles of international remittances (Imai et al. 2011). In this case, remittances are likely to reduce poverty headcount at US $\$ 2$ by $0.9 \%$ in response to a $10 \%$ increase in remittances ceteris paribus. If we apply the same model to headcount ratio at US\$1.25, the coefficient estimate is -0.175 and is significant at the $5 \%$ level. That is, poverty headcount at US\$1.25 is reduced by $1.75 \%$ in response to a $10 \%$ increase in remittances. ${ }^{16}$ 'MFI loans' seems to play an important role in reducing poverty at US\$2 with the coefficient estimate of -0.203 and $t$ value of 1.503 . A $10 \%$ increase in MFI loan portfolio tends to reduce poverty by $2.03 \%$.

GDP deflator is positive and significant in Case 6. In this case, price increase has a poverty increasing effect. A higher dependency ratio tends to be associated with a higher level of poverty. It is noted that the global financial crisis is positive and significant in Cases

\footnotetext{
${ }^{16}$ The results for poverty headcount ratio at US\$1.25 will be furnished on request.
} 
$1,2,8,9$, and 10 . That is, poverty levels during the crisis are generally lower than those in the non-crisis periods ceteris paribus.

\section{Concluding Observations}

Building on the recent literature on finance, growth and hunger, we have examined the experience of Asian countries over the period 1960-2010 by dynamic and static panel data models. We have first examined the effect of various forms of finance, such as private credit, loans from microfinance institutions (MFIs), loans from the World Bank group, and remittances. In the cases where finance is defined as private credit given by banks, we found evidence favouring a positive role of finance on growth of GDP and agricultural value added. While the literature suggests that GDP growth also causes financial development (e.g. Beck et al., 2007), we do not find clear evidence of a reverse causality between GDP growth and financial development. Financial development does not much reduce the Gini coefficient of income distribution, but it reduces undernourishment, if financial development is defined as share of private credit in GDP or as loans from the World Bank, the results of which are consistent with the role of financial development in reducing undernourishment. While it is not clear whether aggregate finance reduces poverty, remittances as well as loans from microfinance institutions seem to have some poverty reducing roles.

We have also examined whether growth, finance, and undernourishment or poverty change during the Asian financial crisis and the recent global financial crisis. Our analysis suggests that 'trade effects' or 'finance effects' are different during the crisis periods. Whilst we find a significant 'trade effect' for private credit as well as loans from the World Bank group during the Asian financial crisis in 1997-98, that is, the effect of trade openness on growth was dampened during the Asian financial crisis, such an effect was not observed during the recent global financial crisis in 2008-2009. On the 'finance effects', these were 
negative and significant for the loans from the World Bank group during the Asian financial crisis. But the effect of loans from the World Bank group was significantly higher during the recent global financial crisis in 2008-9. It is also noted that poverty levels are generally lower in the period of global financial and economic crisis than in other periods other things being equal.

These results are broadly consistent with other analyses in this special volume However, our empirical analysis using cross-country panel data in Asia over the last five decades shows that growth performance was significantly lower during the recent global financial crisis than in non-crisis periods, though the severity was much considerably lower during the former relative to the Asian financial crisis. Remittances as well as microfinance also helped reduce poverty to some extent. However, this does not imply that poverty or undernourishment after the crisis is not important as the poverty rate is still high in many countries-particularly in South Asian countries including India, Bangladesh, Pakistan, or Nepal.

\section{References}

ADB (Asian Development Bank). 2008. Navigating the Global Storm: A Policy Brief on the Global Financial Crisis. Manila: ADB.

ADB (Asian Development Bank). 2010. Outlook 2010. Manila: ADB.

Arellano M, Bond S. 1991. Some tests of specification for panel data: Monte Carlo evidence and an application to employment equations. Review of Economic Studies 58: 277-297.

Arrow K. 2008. Risky Business, The Guardian, 15 October, http://www.guardian.co.uk/commentisfree/cifamerica/2008/oct/15/kenneth-arroweconomy-crisis. 
Baltagi BH. 2005. Econometric Analysis of Panel Data, Third Edition. Chichester: John Wiley \& Sons Ltd.

Baltagi BH, Demetriades PO, Law S H. 2009. Financial development and openness: Evidence from panel data. Journal of Development Economics 89(2): 285-296.

Barro RJ, Lee J. 2000. International Data on Educational Attainment: Updates and Implications. CID Working Paper No. 42, April 2000. Cambridge, MA: Harvard University.

Beck T, Demirgüç-Kunt A. 2009. Financial Institutions and Markets Across Countries and over Time: Data and Analysis. World Bank Policy Research Working Paper No. 4943, May 2009. Washington DC: World Bank.

Beck T, Demirgüç-Kunt A., Levine R. 2007. Finance, Inequality and the Poor. Journal of Economic Growth 12(1), 27-49.

Beck T., Demirgüç-Kunt A., Levine R. 2000. A New Database on Financial Development and Structure. World Bank Economic Review 14, 597-605.

Blundell R, Bond S. 1998. Initial conditions and moment restrictions in dynamic panel-0data models. Journal of Econometrics 87: 115-143.

Claessens S, Feijen E. 2006. Finance and Hunger: Empirical Evidence of the Agricultural Productivity Channel. World Bank Policy Research Working Paper 4080, December 2006, Washington DC: World Bank.

Dasgupta P, Ray, D. 1986. Inequality as a determinant of malnutrition and unemployment: Theory. Economic Journal 96: 1011-1034.

Dercon S, Christiaensen L. 2011. Consumption risk, technology adoption and poverty traps: evidence from Ethiopia. Journal of Development Economics 96(2): 159-173.

FAO. 2008. FAO-STAT, Rome: FAO. http://faostat.fao.org/default.aspx. FAO. 2009. The State of Food Insecurity in the World. Rome: FAO. 
Fosu AK. 2013. The Global Financial Crisis and Development: Whither Africa?. Draft.

Gaiha R, Imai K. 2009. Measuring Vulnerability and Poverty in Rural India. Vulnerability in Developing Countries, Naudé W, Santos-Paulino A, McGillivray M. (Eds.) United Nations University press: Tokyo, 13-54.

Guariglia A, Poncet S. 2008. Could financial distortions be no impediment to economic growth after all? Evidence from China. Journal of Comparative Economics 36(4), 633-657.

Honohan P. 2003. Financial Development, Growth and Poverty: How Close are the Links?. World Bank Policy Research Working Paper 3203, Washington DC: World Bank.

Imai, KS, Arun T, Annim, SK. 2010. Microfinance and Household Poverty Reduction: New evidence from India. World Development 38(12), 1760-1774.

Imai, KS, Gaiha, R, Thapa G. 2010. Is the Millennium Development Goal of Poverty Still Achievable? Role of Institutions, Finance and Openness. Oxford Development Studies 38(3): 309-337.

Imai KS, Gaiha R, Ali A, Kaicker N. 2011. Remittances, Growth and Poverty: New Evidence from Asian Countries. RIEB Discussion Paper Series DP2011-30, Kobe: Kobe University.

Imai KS, Gaiha R., Thapa G., Annim, SK. 2012. Microfinance and Poverty: A Macro Perspective. World Development 40(8): 1675-1689.

IMF (International Monetary Fund). 2008. World Economic Outlook. October 2008, Washington DC: IMF.

IMF (International Monetary Fund). 2010. World Economic Outlook. October 2010, Washington DC: IMF.

Ivanic M, Martin W. 2008. Implications of higher global food prices for poverty in lowincome countries-super-1. Agricultural Economics 39(s1): 405-416.

Jha R., Gaiha R., Sharma A. 2009. Calorie and Micronutrient Deprivation and Poverty Nutrition Traps in Rural India. World Development 37(5): 982-991. 
Krugman, P. 2008. The International Finance Multiplier. New York Times, http://www.princeton.edu/ pkrugman/finmult.pdf.

Lin JY, Martin W. 2010. The financial crisis and its impacts on global agriculture. Agricultural Economics. 41(s1): 133-144.

Littlefield E., Morduch J., Hashemi S. 2003. Is Microfinance an effective Strategy to reach the Millennium Development Goals? Focus Note 24, CGAP. http://www.cgap.org/p/site/c/template.rc/1.9.2568/.

Lokshin M, Ravallion M. 2000. Welfare Impacts of the 1998 Financial Crisis in Russia and the Response of the Public Safety Net. Economics of Transition 8(2). 269-295.

Mazumdar D, Horton S. 2000. Impact of Asian Financial Crisis on Labour Markets, Income Distribution and Poverty: A Comparative Study of Five Countries. Indian Journal of Labour Economics 43(3): 451-65.

Microcredit Summit Campaign. 2008. Addressing the global financial crisis and fluctuating food and fuel costs. Micro-credit Summit E-news 6(2) October 2008, http://www.microcreditsummit.org/enews/2008-10_africa.html.

McCulloch N, Grover, A. 2013. Estimating the Impact of a financial Crisis - Combining Rapid Qualitative studies with Nationally Representative Surveys, Draft.

Nixson F, Walters B. 1999. The Asian Crisis: Causes and Consequences. Manchester School 67(5). 496-523.

Oscar A. 2008. Income Distribution and Poverty through Crisis and Adjustment. CEPAL Review 96, 97-122.

Phelps E. 2008. What Has Gone Wrong up until Now. Spiegel Online, 11 November http://www.spiegel.de/international/world/0,1518,590030,00.html.

Rodrik D. 2010. Can Developing Countries Carry the World Economy? Project Syndicate, http://www.project-syndicate.org/commentary/rodrik49/English. 
Stillman S., Thomas D. 2008. Nutritional Status during an Economic Crisis: Evidence from Russia. Economic Journal 118(531): 1385-1417.

UNU-WIDER. 2008. UNU-WIDER World Income Inequality Database, Version 2.0c. May 2008, Helsinki: UNU-WIDER, available from http://www.wider.unu.edu/research/Database/en_GB/database/.

Wagner C, Winkler A. 2012. The vulnerability of microfinance to financial turmoil evidence from the global financial crisis. Mimeo., Frankfurt School of Finance \& Management.

World Bank. 2008a. Global Financial Crisis and Implications for Developing Countries. A Background Paper for G-20 Finance Ministers' Meeting, Sao Paulo, Brazil, November 8. World Bank. 2012. World Development Indicator 2012. Washington D.C.: World Bank. 
Table 1 Summary of Growth, Poverty, Finance, and Export performances at regional levels

\begin{tabular}{|c|c|c|c|c|c|c|c|}
\hline \multicolumn{4}{|c|}{ (a) Before and After the Asian Financial Crisis } & \multicolumn{4}{|c|}{ (b) Before and After the Global Financial Crisis } \\
\hline & $\begin{array}{c}\text { East } \\
\text { Asia } \\
\& \\
\text { Pacific } \\
\end{array}$ & $\begin{array}{l}\text { South } \\
\text { Asia }\end{array}$ & $\begin{array}{l}\text { Sub- } \\
\text { Saharan } \\
\text { Africa } \\
\end{array}$ & & $\begin{array}{c}\text { East } \\
\text { Asia } \\
\& \\
\text { Pacific } \\
\end{array}$ & $\begin{array}{l}\text { South } \\
\text { Asia } \\
\end{array}$ & $\begin{array}{l}\text { Sub- } \\
\text { Saharan } \\
\text { Africa }\end{array}$ \\
\hline \multicolumn{8}{|c|}{ GDP per capita growth (\%) } \\
\hline 1995 & 8.5 & 4.8 & 1.1 & 2005 & 8.9 & 7.0 & 3.1 \\
\hline 1996 (pre-crisis) & 7.7 & 4.8 & 2.3 & 2006 (pre-crisis) & 10.1 & 7.0 & 3.7 \\
\hline \multirow{3}{*}{$\begin{array}{c}1998 \\
\text { change from the pre-crisis } \\
\text { level }\end{array}$} & 6.0 & 1.8 & 0.9 & 2007 & 11.5 & 7.4 & 3.9 \\
\hline & 1.1 & 3.6 & -0.2 & \multirow{2}{*}{$\begin{array}{c}2008 \\
\text { change from the pre-crisis } \\
\text { level }\end{array}$} & 7.7 & 3.2 & 2.4 \\
\hline & -6.6 & -1.2 & -2.5 & & -2.4 & -3.8 & -1.3 \\
\hline 1999 & 5.2 & 4.7 & -0.1 & 2009 & 6.7 & 6.5 & -0.5 \\
\hline \multirow{2}{*}{$\begin{array}{c}2000 \\
\text { change from the pre-crisis } \\
\text { level }\end{array}$} & 6.5 & 2.4 & 1.0 & \multirow{2}{*}{$\begin{array}{c}2010 \\
\text { change from the pre-crisis } \\
\text { level }\end{array}$} & 8.9 & 6.6 & 2.6 \\
\hline & -1.2 & -2.3 & -1.3 & & -1.2 & -0.5 & -1.1 \\
\hline \multicolumn{4}{|c|}{ Poverty headcount ratio at $\$ 2$ a day (PPP) $(\%)^{\star}$} & \multicolumn{4}{|c|}{ Poverty headcount ratio at $\$ 2$ a day (PPP) $(\%)^{\star}$} \\
\hline \multirow{3}{*}{$\begin{array}{c}1996 \text { (pre-crisis) } \\
1999 \\
\text { change from the pre-crisis } \\
\text { level } \\
\end{array}$} & 64.0 & 80.7 & 77.5 & 2005 (pre-crisis) & 39.0 & 73.4 & 74.1 \\
\hline & 61.7 & 77.8 & 77.4 & $\begin{array}{c}2008 \\
\text { change from the pre-crisis }\end{array}$ & 33.2 & 70.9 & 69.2 \\
\hline & -2.2 & -2.9 & -0.1 & level & -5.8 & -2.5 & -4.9 \\
\hline \multicolumn{4}{|l|}{ Private Credit/GDP (\%) } & \multicolumn{4}{|l|}{ Private Credit/GDP (\%) } \\
\hline 1995 & 85.3 & 23.0 & 62.5 & 2005 & 99.9 & 37.7 & 62.2 \\
\hline 1996 (pre-crisis) & 91.1 & 23.8 & 59.3 & 2006 (pre-crisis) & 97.1 & 40.8 & 64.9 \\
\hline 1997 & 98.8 & 24.0 & 58.2 & 2007 & 96.7 & 42.5 & 66.9 \\
\hline \multirow{2}{*}{$\begin{array}{c}1998 \\
\text { change from the pre-crisis } \\
\text { level }\end{array}$} & 103.6 & 24.2 & 57.4 & \multirow{2}{*}{$\begin{array}{c}2008 \\
\text { change from the pre-crisis } \\
\text { level }\end{array}$} & 94.3 & 45.6 & 56.9 \\
\hline & 12.4 & 0.4 & -1.9 & & -2.8 & 4.8 & -8.0 \\
\hline 1999 & 100.6 & 25.8 & 64.3 & 2009 & 114.5 & 43.5 & 63.8 \\
\hline \multirow{2}{*}{$\begin{array}{c}2000 \\
\text { change from the pre-crisis } \\
\text { level }\end{array}$} & 98.6 & 27.7 & 60.9 & \multirow{2}{*}{$\begin{array}{c}2010 \\
\text { change from the pre-crisis } \\
\text { level }\end{array}$} & 116.3 & 45.8 & 64.8 \\
\hline & 7.5 & 3.9 & 1.6 & & 19.2 & 5.0 & -0.1 \\
\hline \multicolumn{4}{|c|}{ Export (goods and services) /GDP (\%) } & \multicolumn{4}{|c|}{ Export (goods and services) /GDP (\%) } \\
\hline 1995 & 27.4 & 12.5 & 27.8 & 2005 & 44.9 & 19.1 & 32.5 \\
\hline 1996 (pre-crisis) & 27.2 & 12.1 & 29.8 & 2006 (pre-crisis) & 46.2 & 20.5 & 33.3 \\
\hline 1997 & 29.9 & 12.4 & 28.7 & 2007 & 45.1 & 19.9 & 33.7 \\
\hline \multirow{2}{*}{$\begin{array}{c}1998 \\
\text { change from the pre-crisis } \\
\text { level }\end{array}$} & 32.7 & 12.8 & 27.5 & \multirow{2}{*}{$\begin{array}{c}2008 \\
\text { change from the pre-crisis } \\
\text { level }\end{array}$} & 42.3 & 22.3 & 36.1 \\
\hline & 5.5 & 0.7 & -2.2 & & -3.9 & 1.7 & 2.8 \\
\hline 1999 & 31.6 & 13.0 & 28.3 & 2009 & 34.5 & 19.1 & 29.9 \\
\hline \multirow{2}{*}{$\begin{array}{c}2000 \\
\text { change from the pre-crisis } \\
\text { level }\end{array}$} & 35.3 & 14.2 & 32.3 & \multirow{2}{*}{$\begin{array}{c}2010 \\
\text { change from the pre-crisis } \\
\text { level }\end{array}$} & 37.2 & 20.3 & 31.1 \\
\hline & 8.1 & 2.1 & 2.5 & & -9.0 & -0.2 & -2.1 \\
\hline
\end{tabular}


Table 2 Results for the Growth Equation (Blundell-Bond GMM estimation: Dependent Variable: $\log$ GDP per capita)

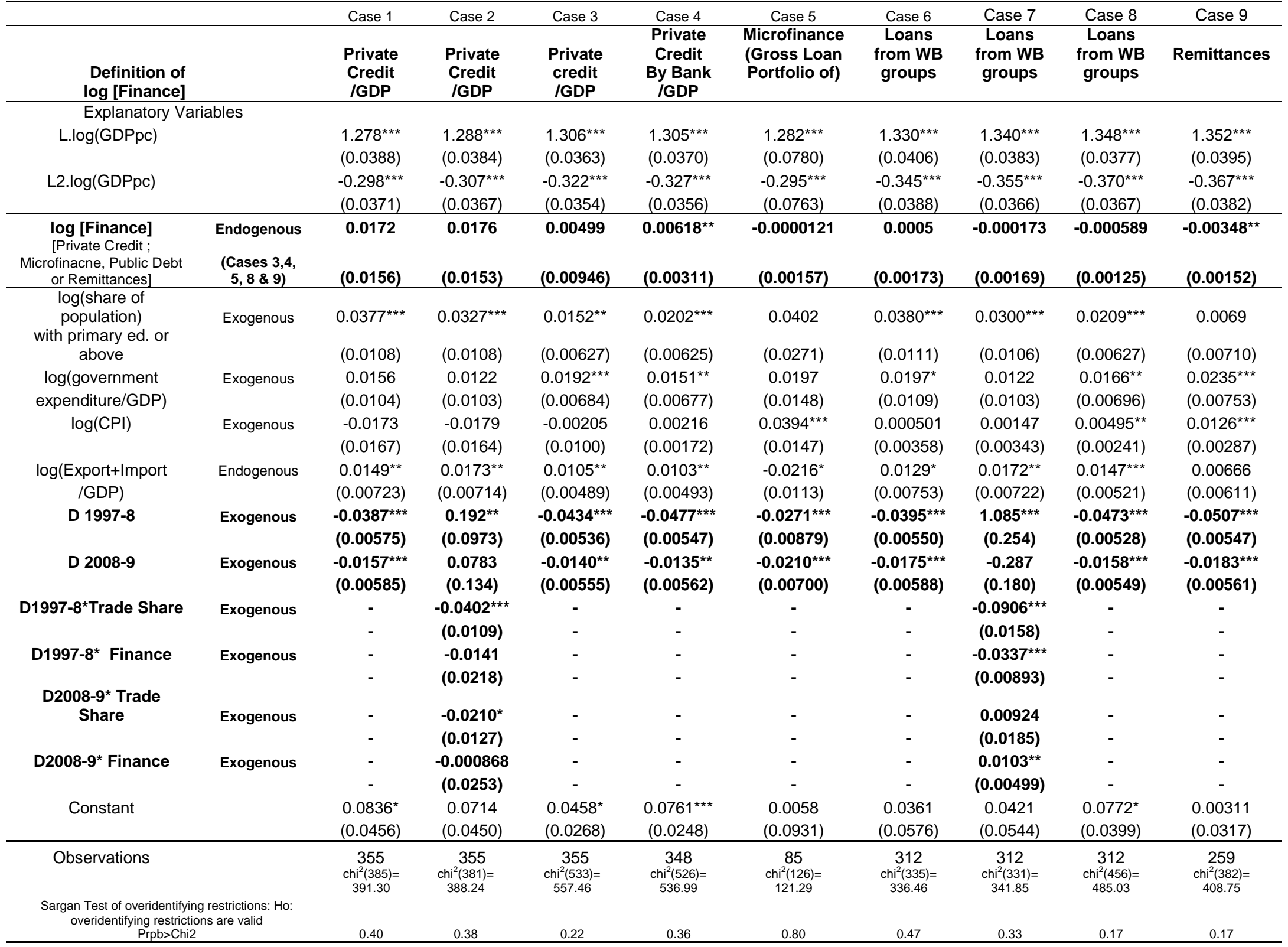


Standard errors in parentheses: ${ }^{\star \star *} p<0.01,{ }^{* \star} p<0.05,{ }^{*} p<0.1$. 3. Blundell and Bond (1998) GMM one-step estimator is applied for all the cases. 
Table 3 Results for the Finance Equation (Blundell-Bond GMM estimation ${ }^{* 2}$; Dependent Variable: Finance)

\begin{tabular}{|c|c|c|c|c|c|c|}
\hline & & Case 1 & Case 2 & Case 3 & Case 4 & Case 5 \\
\hline $\begin{array}{r}\text { Dep. Variable } \\
\text { (in log) }\end{array}$ & & $\begin{array}{l}\text { Private } \\
\text { credit/ } \\
\text { /GDP }\end{array}$ & $\begin{array}{c}\text { Private } \\
\text { Credit by } \\
\text { Banks/GDP }\end{array}$ & $\begin{array}{l}\text { Microfinance } \\
\text { (Gross Loan } \\
\text { Portfolio of) }\end{array}$ & $\begin{array}{l}\text { Loans } \\
\text { from WB } \\
\text { groups }\end{array}$ & Remittances \\
\hline \multicolumn{7}{|l|}{ Explanatory Variables } \\
\hline \multirow[t]{2}{*}{ L. } & & $1.478^{* * *}$ & $1.075^{\star \star *}$ & $0.717^{\star * *}$ & $1.443^{\star * *}$ & $0.953^{* * *}$ \\
\hline & & $(0.0275)$ & $(0.0356)$ & $(0.0673)$ & $(0.0367)$ & $(0.0415)$ \\
\hline \multirow[t]{2}{*}{ L2. } & & $-0.530^{\star \star \star}$ & $-0.125^{\star \star \star}$ & $0.200^{\star \star *}$ & $-0.394^{* \star *}$ & 0.0121 \\
\hline & & $(0.0253)$ & $(0.0345)$ & $(0.0577)$ & $(0.0333)$ & $(0.0394)$ \\
\hline \multirow[t]{2}{*}{$\log$ (GDP per capita) } & Endogenous & 0.0116 & -0.00444 & 0.252 & $-0.345^{\star \star \star}$ & -0.0923 \\
\hline & (Cases 2, 4, \& 6) & $(0.0176)$ & $(0.0181)$ & $(0.162)$ & $(0.0409)$ & $(0.0563)$ \\
\hline \multirow[t]{2}{*}{$\log ($ Export+lmport/GDP) } & Endogenous & $0.0347^{\star}$ & 0.0179 & $-0.580^{\star \star \star}$ & $0.135^{\star \star \star}$ & 0.0624 \\
\hline & (Cases 3, 4, \& 6) & $(0.0203)$ & $(0.0188)$ & $(0.188)$ & $(0.0469)$ & $(0.0619)$ \\
\hline \multirow[t]{2}{*}{ D 1997-8 } & & $0.0617^{* * *}$ & 0.00799 & $1.438^{\star * *}$ & 0.039 & $0.100^{\star *}$ \\
\hline & & $(0.0235)$ & $(0.0207)$ & $(0.255)$ & $(0.0523)$ & $(0.0497)$ \\
\hline \multirow[t]{2}{*}{ D 2008-9 } & & $0.0487^{\star *}$ & 0.0243 & -0.188 & $0.131^{\star *}$ & -0.0207 \\
\hline & & $(0.0245)$ & $(0.0208)$ & $(0.121)$ & $(0.0531)$ & $(0.0499)$ \\
\hline \multirow[t]{2}{*}{ Constant } & & 0.0193 & $0.183^{* * *}$ & $2.834^{\star * *}$ & $0.682^{* * *}$ & $0.423^{* *}$ \\
\hline & & $(0.0669)$ & $(0.0586)$ & $(0.996)$ & $(0.247)$ & $(0.193)$ \\
\hline Observations & & 403 & 361 & 69 & 323 & 253 \\
\hline Number of Country & & 9 & 9 & 8 & 9 & 9 \\
\hline \multicolumn{7}{|c|}{ Sargan Test of overidentifying restrictions Ho: overidentifying restrictions are valid } \\
\hline & & $\operatorname{chi}^{2}(535)=$ & $\operatorname{chi}^{2}(493)=$ & $\operatorname{chi}^{2}(94)=$ & $\operatorname{chi}^{2}(425)=$ & $\operatorname{chi}^{2}(339)=$ \\
\hline & & 700.23 & 552.36 & 195.92 & 965.09 & 363.15 \\
\hline Prpb $>$ Chi2 & & 0.00 & 0.03 & 0.00 & 0.00 & 0.18 \\
\hline \multicolumn{7}{|c|}{$\begin{array}{l}\text { The coefficient estimates for GDP per capita and trade share in the cases where these are treated as exogenous } \\
\text { variables and crisis dummy variables excluded. }{ }^{3} \text {. }\end{array}$} \\
\hline \multirow[t]{2}{*}{ log(GDP per capita) } & Exogenous & $0.0363^{\star}$ & 0.0006 & $0.793^{\star \star \star}$ & $-0.429^{\star \star \star}$ & -0.037 \\
\hline & & $(0.0210)$ & $(0.0213)$ & $(0.256)$ & $(0.0511)$ & $(0.0649)$ \\
\hline \multirow[t]{2}{*}{$\log ($ Export+Import/GDP) } & Exogenous & $0.0533^{\star \star}$ & 0.0233 & $-0.699^{\star \star}$ & $0.102^{\star}$ & 0.0116 \\
\hline & & $(0.0237)$ & $(0.0188)$ & $(0.301)$ & $(0.0588)$ & $(0.0713)$ \\
\hline
\end{tabular}

Notes: ${ }^{1}$ Standard errors in parentheses: ${ }^{\star \star \star} \mathrm{p}<0.01,{ }^{* \star} \mathrm{p}<0.05,{ }^{*} \mathrm{p}<0.1$

2. Blundell and Bond (1998) GMM one-step estimator is applied for all the cases.

3. A full set of results will be provided on request. 
Table 4 Results for the Inequality or Undernourishment Equation (Fixed or Random Effects Model)

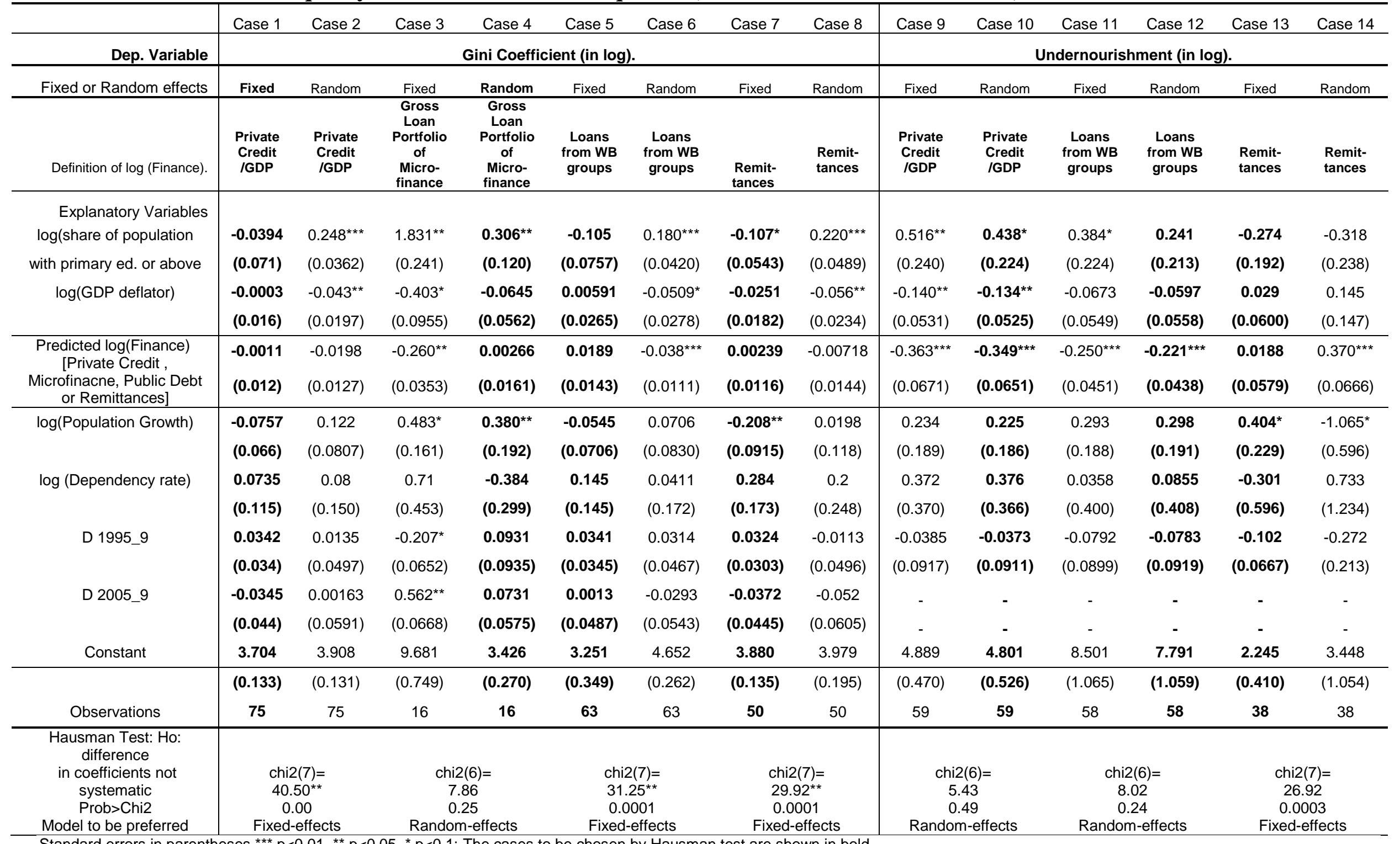

Standard errors in parentheses ${ }^{* * *} p<0.01,{ }^{* *} p<0.05,{ }^{*} p<0.1$; The cases to be chosen by Hausman test are shown in bold. 
Table 5 Results for Poverty Equation for Poverty Headcount Ratio at US\$2 (Fixed or Random Effects Model)

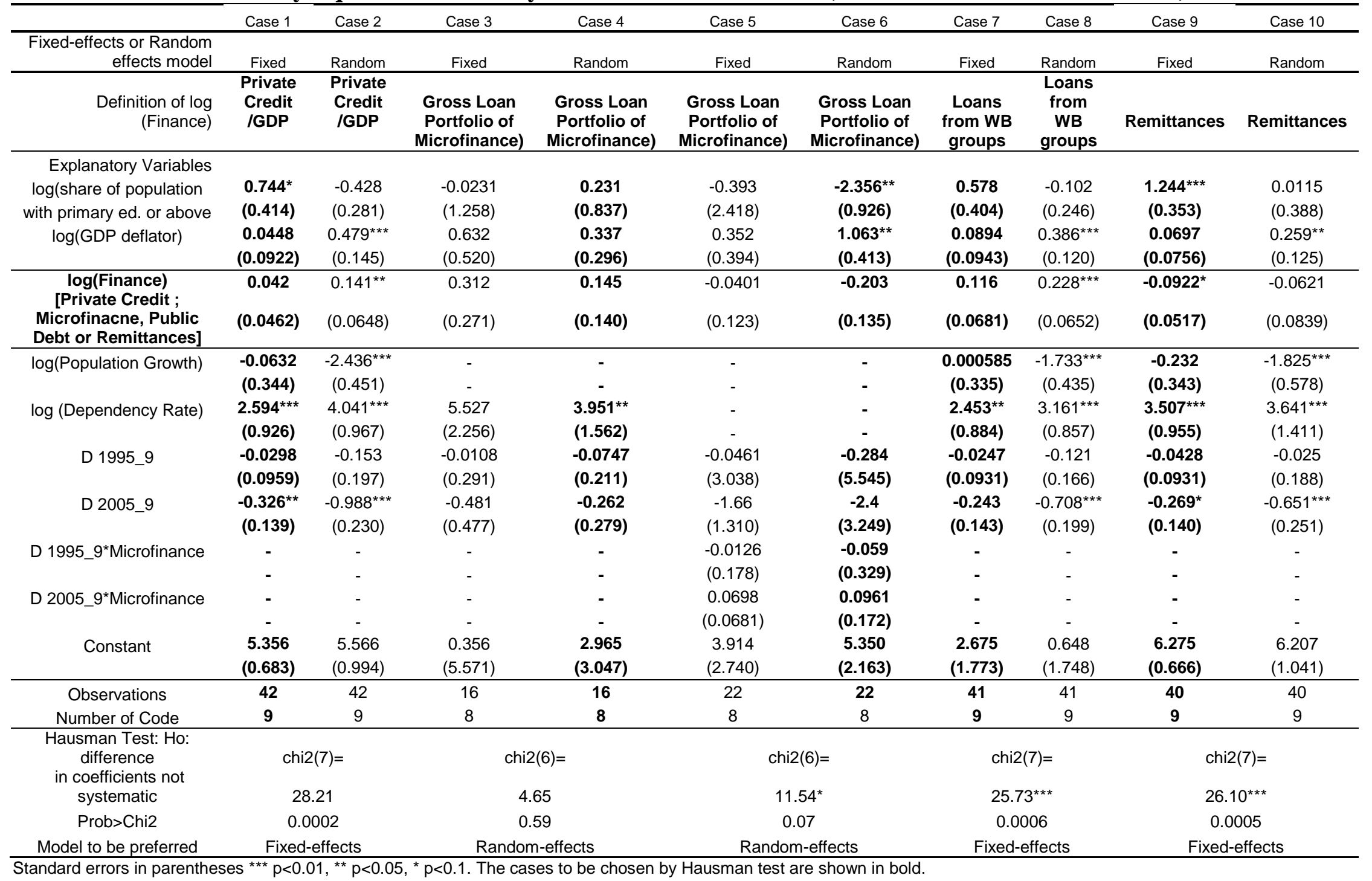


Appendix 1 Summary of Growth, Poverty, Finance, and Export performances at country levels - before and after the Asian Financial Crisis

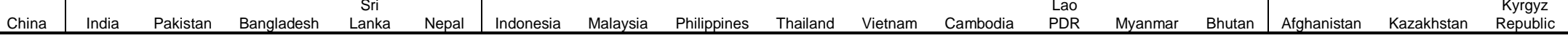

Poverty headcount ratio at $\$ 1.25$ a day (PPP) (\%)

\begin{tabular}{|c|c|c|c|c|c|c|c|c|c|c|c|c|c|c|c|c|c|c|}
\hline 1995 & 54.1 & . & . & . & 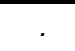 & . & . & 2.1 & . & & . & . & . & . & . & . & . & . \\
\hline 1996 & 36.4 & . & . & 60.9 & 16.3 & 68.0 & 43.4 & . & . & 2.5 & . & . & . & . & . & . & 5.0 & . \\
\hline 1997 & 47.8 & . & 48.1 & . & . & . & . & 0.5 & 21.6 & & . & . & 49.3 & . & . & . & . & . \\
\hline 1998 & 48.0 & . & . & . & . & . & . & . & . & 2.1 & 49.7 & . & . & . & . & . & . & 31.8 \\
\hline 2000 & . & . & . & 58.6 & . & . & . & . & 22.5 & 3.0 & . & . & . & . & . & . & . & . \\
\hline
\end{tabular}

Poverty headcount ratio at $\$ 2$ a day (PPP)

\begin{tabular}{|c|c|c|c|c|c|c|c|c|c|c|c|c|c|c|c|c|c|c|}
\hline 1995 & 74.1 & . & . & . & . & & & 11.0 & . & . & . & . & . & . & . & . & & . \\
\hline 1996 & 65.1 & . & . & 85.5 & 46.7 & 89.0 & 77.0 & . & . & 14.6 & . & . & . & . & . & . & 18.8 & . \\
\hline 1997 & 70.8 & . & 83.3 & . & . & 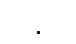 & 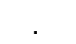 & 6.8 & 43.8 & . & . & . & 79.9 & . & . & . & . & . \\
\hline 1998 & 69.6 & . & $\cdot$ & . & . & . & . & . & . & 15.3 & 78.3 & . & . & . & . & . & . & 60.8 \\
\hline 2000 & & . & - & 84.4 & . & . & . & . & 44.8 & 18.1 & . & . & . & . & . & . & . & . \\
\hline \multicolumn{19}{|c|}{ Private Credit/GDP (\%) } \\
\hline 1995 & 85.0 & 22.8 & 24.2 & 20.9 & 31.1 & 22.8 & 53.5 & 124.4 & 37.5 & 139.8 & 18.5 & 3.5 & 9.1 & 7.6 & 8.1 & . & 7.1 & 12.5 \\
\hline 1996 & 90.3 & 23.7 & 24.7 & 21.6 & 29.9 & 23.2 & 55.5 & 141.6 & 49.0 & 147.2 & 18.7 & 4.7 & 9.0 & 9.6 & 7.0 & . & 6.3 & 8.7 \\
\hline 1997 & 97.6 & 23.8 & 24.6 & 22.8 & 29.4 & 23.9 & 60.8 & 158.4 & 56.5 & 165.7 & 19.8 & 6.3 & 13.0 & 10.3 & 11.8 & . & 5.2 & 3.5 \\
\hline 1998 & 106.2 & 24.0 & 25.1 & 23.2 & 28.7 & 28.7 & 53.2 & 158.5 & 43.3 & 155.9 & 20.1 & 5.6 & 12.6 & 9.7 & 10.0 & . & 6.4 & 5.3 \\
\hline 1999 & 111.5 & 25.9 & 25.5 & 23.5 & 29.3 & 28.9 & 20.6 & 149.2 & 38.5 & 131.9 & 28.2 & 5.7 & 8.4 & 8.1 & 8.7 & . & 8.2 & 5.1 \\
\hline 2000 & 112.3 & 28.8 & 22.3 & 24.7 & 28.8 & 30.7 & 19.9 & 135.0 & 36.8 & 108.3 & 35.3 & 6.4 & 8.9 & 9.5 & 9.1 & . & 11.2 & 4.2 \\
\hline \multicolumn{19}{|c|}{ Export/GDP (\%) } \\
\hline 1995 & 20.2 & 11.0 & 16.7 & 10.9 & 35.6 & 25.0 & 26.3 & 94.1 & 36.4 & 41.8 & 32.8 & 31.2 & 23.2 & 0.8 & 40.0 & . & 39.0 & 29.5 \\
\hline 1996 & 20.1 & 10.5 & 16.9 & 11.1 & 35.0 & 22.8 & 25.8 & 91.6 & 40.5 & 39.3 & 40.9 & 25.4 & 22.7 & 0.7 & 37.3 & . & 35.3 & 30.7 \\
\hline 1997 & 21.8 & 10.8 & 16.1 & 12.0 & 36.5 & 26.3 & 27.9 & 93.3 & 49.0 & 48.0 & 43.1 & 33.6 & 23.9 & 0.6 & 38.3 & . & 34.9 & 38.3 \\
\hline 2000 & 23.3 & 13.2 & 13.4 & 14.0 & 39.0 & 23.3 & 41.0 & 119.8 & 51.4 & 66.8 & 55.0 & 49.8 & 30.0 & 0.5 & 30.5 & . & 56.6 & 41.8 \\
\hline
\end{tabular}


Source: World Bank (2012). 
Appendix 2 Summary of Growth, Poverty, Finance, and Export performances at country levels (before and after the Global Financial Crisis)

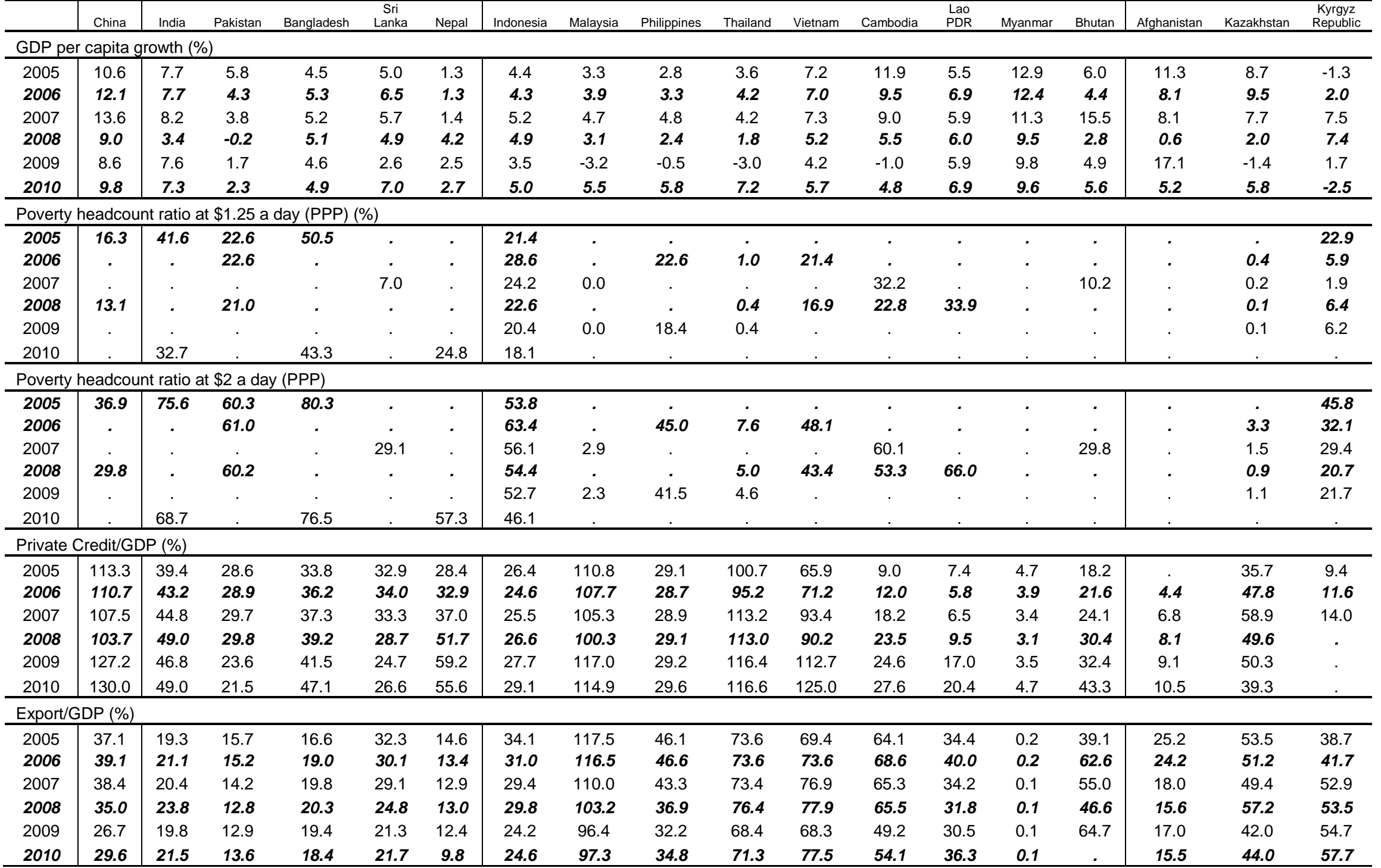

Source: World Bank (2012) 
Appendix 3 Definitions and Descriptive Statistics of the Variables

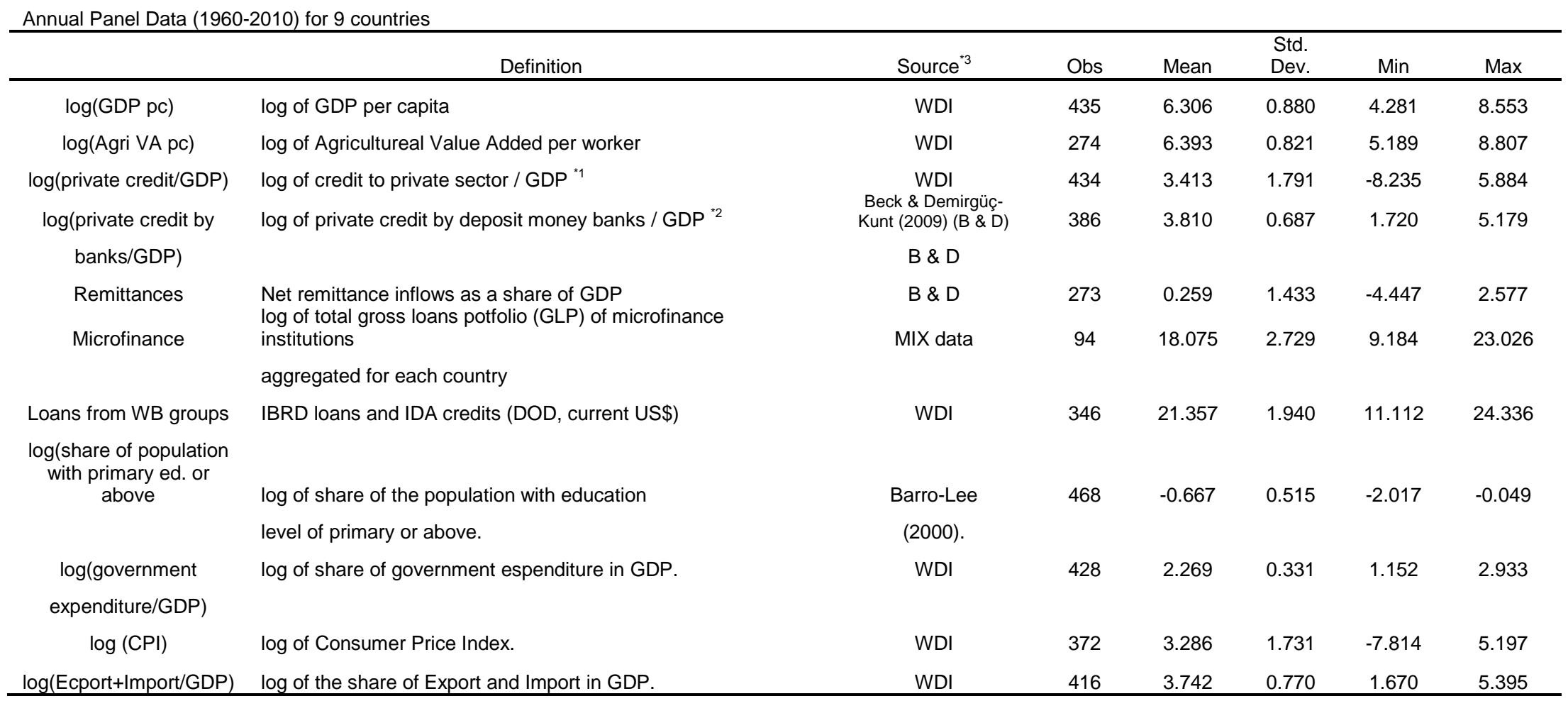


Appendix 3 - Definitions and Descriptive Statistics of the Variables (Cont.)

\begin{tabular}{|c|c|c|c|c|c|c|c|}
\hline Variable & Definition & Source ${ }^{* 3}$ & Obs & Mean & $\begin{array}{l}\text { Std. } \\
\text { Dev. }\end{array}$ & Min & $\operatorname{Max}$ \\
\hline GINI & $\begin{array}{l}\text { log of GINI coefficient of income or consumption at naional } \\
\text { level. } \\
\text { The share of population below minimum level of dietary } \\
\text { energy consumption (also referred to as prevalence of } \\
\text { undernourishment) which shows the percentage of the } \\
\text { population whose food intake is insufficient to meet dietary }\end{array}$ & UNU-WIDER. & 74 & 3.650 & 0.181 & 3.316 & 4.036 \\
\hline Undernourishment & energy requirements continuously. & WDI & 63 & 3.015 & 0.778 & 0.916 & 3.932 \\
\hline $\begin{array}{l}\text { Poverty Headcount Ratio } \\
\text { (US } \$ 1.25)\end{array}$ & Poverty headcount ratio at $\$ 2$ a day (PPP) (\% of population) & WDI & 52 & 3.862 & 0.851 & 0.947 & 4.557 \\
\hline $\begin{array}{l}\text { Poverty Headcount Ratio } \\
\text { (US } \$ 2.0)\end{array}$ & Poverty headcount ratio at $\$ 2$ a day (PPP) (\% of population) & WDI & 51 & 3.128 & 1.324 & -0.660 & 4.336 \\
\hline $\log \left(\right.$ private credit/GDP) ${ }^{* 1}$ & $\log$ of share of domestic credit provided by & $B \& D$ & 91 & 3.608 & 1.695 & -6.209 & 5.767 \\
\hline Microfinance & $\begin{array}{l}\text { banking sector in GDP. } \\
\text { log of total gross loans potfolio (GLP) of microfinance } \\
\text { institutions }\end{array}$ & MIX data & 25 & 18.469 & 2.229 & 15.160 & 22.811 \\
\hline & aggregated for each country & & & & & & \\
\hline Loans from WB groups & IBRD loans and IDA credits (DOD, current US\$) & & 76 & 21.520 & 1.803 & 16.486 & 24.389 \\
\hline $\begin{array}{l}\log (\text { share of population } \\
\text { with primary ed. or above }\end{array}$ & $\begin{array}{l}\text { log of average schooling years of people above } 15 \text { years old } \\
\text { in the initial year. }\end{array}$ & $\begin{array}{l}\text { Barro-Lee } \\
\text { (2011). }\end{array}$ & 99 & -0.645 & 0.514 & -2.017 & -0.049 \\
\hline $\log ($ GDP deflator) & $\begin{array}{l}\text { Inflation as measured by the annual growth rate } \\
\text { of the GDP implicit deflator. }\end{array}$ & WDI & 90 & 1.926 & 1.012 & -0.697 & 5.847 \\
\hline $\log ($ Ecport+lmport/GDP) & log of the share of Export and Import in GDP. & WDI & 91 & 3.781 & 0.764 & 1.947 & 5.325 \\
\hline $\log ($ Population Growth) & log of annual popuoation growth & WDI & 99 & 0.640 & 0.416 & -0.657 & 1.227 \\
\hline log (Dependency Burden) & the ratio of dependents--people younger than 15 or & WDI & 90 & -0.320 & 0.219 & -0.892 & -0.035 \\
\hline
\end{tabular}

*1 Domestic credit provided by the banking sector includes all credit to various sectors on a gross basis, with the exception of credit to the central government, which is net. The banking sector includes monetary authorities and deposit money banks, as well as other banking institutions where data are available (including institutions that do not accept transferable deposits but do incur such liabilities as time and savings deposits). Examples of other banking institutions are savings and mortgage loan institutions and building and loan associations.

*2 This is similar to the first definition, but this is a defined narrowly by covering only private credit through deposit money banks.

*3 WDI data are available on http://data.worldbank.org/data-catalog/world-development-indicators. Finance data cited by Beck \& Demirgüç-Kunt (2009) are available on

http://econ.worldbank.org/WBSITE/EXTERNAL/EXTDEC/EXTRESEARCH/0, contentMDK:20696167 pagePK:64214825 piPK:64214943 theSitePK:469382,00.html. MIX data are available on:

http://www.mixmarket.org/. Inequality data of UNU-WIDER is available on http://www.wider.unu.edu/research/Database/en GB/database/. See http://www.barrolee.com/ for Barro-Lee data. 